Elsevier

GEN 02849

\title{
Expression of synthetic genes encoding bovine and human basic fibroblast growth factors (bFGFs) in Escherichia coli
}

(Recombinant DNA; fusion protein; $\beta$-galactosidase; linker; affinity chromatography; angiogenic capacity)

\author{
W. Knoerzer ${ }^{\text {a }}$, H.-P. Binder ${ }^{b}$, K. Schneider ${ }^{\text {a }}$, P. Gruss ${ }^{\text {c }}$, J.E.G. McCarthy ${ }^{d}$ and W. Risau ${ }^{\mathrm{e}}$ \\ ${ }^{a}$ PROGEN Biotechnik GmbH, Heidelberg (F.R.G.) Tel. 06221403511; ${ }^{b}$ Institut für Molekulare Genetik der Universität, \\ Heidelberg (F.R.G.) Tel.06221562677; ' Max-Planck-Institut für Biophysikalische Chemie, Abt. Molekulare Zellbiologie, \\ Göttingen (F.R.G.) Tel.0551201361; ' Gesellschaft für Biotechnologische Forschung mbH, Braunschweig (F.R.G.) \\ Tel. 053161810, and ${ }^{e}$ Max-Planck-Institut für Psychiatrie, Abt. Neurochemie, Martinsried (F.R.G.) Tel. 08985783625
}

Received by J.-P. Lecocq: 22 June 1988

Accepted: 14 September 1988

\section{SUMMARY}

Synthetic genes encoding bovine and human basic fibroblast growth factors (bFGFs) were assembled and cloned using established Escherichia coli expression plasmids. Transformed $E$. coli cells were able to synthesize either a fusion protein, comprising the first seven amino acids of $\beta$-galactosidase, a linker fragment and bovine FGF, or genomic human bFGF. The two growth factors were purified from $E$. coli lysates by cation exchange and heparin-Sepharose affinity chromatography. The purified recombinant proteins were biologically active as monitored by their mitogenic activity for bovine aortic endothelial cells and their angiogenic capacity in the rabbit cornea.

\section{INTRODUCTION}

The growth of the new capillaries (angiogenesis) is a complex process which involves both the migration and proliferation of vascular endothelial cells (Folkman, 1985). The vascular endothelium of a

Correspondence to: Dr. W. Knoerzer, PROGEN Biotechnik GmbH, Im Neuenheimer Feld 519, 6900 Heidelberg (F.R.G.) Tel. 06221403511; Fax 06221/403535.

Abbreviations: aa, amino acid(s); aFGF, acidic FGF; BAE, bovine aortic endothelial; bFGF, basic FGF; BSA, bovine serum albumin; buffer L, see MATERIALS AND METHODS, section el; DMEM, Dulbecco's modified Eagle's medium; DTT, dithiothreitol; $\mathrm{ED}_{50}$, half-maximal stimulation of cell prolifera- normal adult organism rejuvenates only a few times. On the other hand, a rapid turnover can be seen in various pathophysiological responses such as acute inflammation, wound healing, and tumor angiogenesis (Folkman and Klagsbrun, 1987). Basic FGF (bFGF) has been shown to be a very potent mitogen

tion; Elvax, ethylene vinyl acetate; FCS, fetal calf serum; FGF, fibroblast growth factor; HPLC, high-performance liquid chromatography; nt, nucleotide(s); oligo, oligodeoxyribonucleotide; PAGE, polyacrylamide gel electrophoresis; PBS, phosphatebuffered saline: $137 \mathrm{mM} \mathrm{NaCl}, 2.7 \mathrm{mM} \mathrm{KCl}, 8 \mathrm{mM} \mathrm{Na}_{2} \mathrm{HPO}_{4}$, $1.5 \mathrm{mM} \mathrm{KH} \mathrm{PO}_{4}$, pH 7.4; Pollk, Klenow (large) fragment of $E$. coli DNA polymerase I; SDS, sodium dodecyl sulfate; TIR, translation initiation region; [ ], designates plasmid-carrier state. 
and chemoattractant for endothelial cells in vitro (for review, see Gospodarowicz et al., 1986). It stimulates angiogenesis in vivo on the chick chorioallantoic membrane and rabbit cornea (for review, see Folkman and Klagsbrun, 1987).

Bovine bFGF has been purified and characterized from a wide range of tissues including pituitary, brain, hypothalamus, retina, adrenal gland, thymus, corpus luteum, and kidney (Lobb et al,, 1986; Gospodarowicz et al., 1986). Although the amino acid and nucleotide sequences of both bovine and human bFGF are known (Abraham et al., 1986), little protein material has up to now been available. It is therefore desirable to produce sufficient quantities of recombinant $b F G F$ to be able to tackle questions concerning the biological role of signals that naturally trigger angiogenesis in vivo or to obtain sufficient growth-factor protein for use as an (essential) component for serum-free cell-culture medium.

Here we report the design, assembly, and expression of synthetic genes encoding bovine and human bFGFs. Since bFGF is a single-chain non glycosylated polypeptide, it seemed reasonable to expect that biologically active material might be produced in $E$. coli. Two different vector systems were used to obtain synthesis of the factors in fused and unfused forms. An initial step toward optimization of the direct expression of human bFGF was taken by manipulating the $\mathrm{N}$-terminal part of the synthetic gene so as to allow efficient translational initiation in the pJLA503 expression vector.

\section{MATERIALS AND METHODS}

\section{(a) Reagents and enzymes}

Restriction endonucleases and BSA were purchased from Boehringer Mannheim. Bacteriophage T4 DNA ligase, polynucleotide kinase, Pollk, nucleic-acid-grade agarose, heparin-Sepharose, CL-6B; CM-Sephadex C-50, Bio-Gel-P2, and NAP-10 columns were obtained from Pharmacia. Diisopropyl phosphoramidites were obtained from Applied Biosystems, phosphotriester reagents were obtained from Biosearch; $\left[\alpha^{-35} S\right] d A T P$ and $\left[\gamma_{-}{ }^{32} \mathrm{P}\right]$ ATP were obtained from Amersham; DEAE NA45 membranes and nitrocellulose filters were purchased from Schleicher \& Schuell; the $\mathrm{x}$-ray films
RX were obtained from Fuji; Costar plates were obtained from Costar, Cambridge, MA; PBS, DMEM, and trypsin-EDTA solution were obtained from Gibco; peroxidase-conjugated goat anti-rabbit IgG antibody was purchased from Medac; and Biorad protein assay was obtained from Biorad.

\section{(b) Synthesis and purification of oligodeoxynucle- otides}

Oligos 1-26 were synthesized using phosphotriester chemistry on the Biosearch model Cyclone oligo synthesizer. Oligos were purified by electrophoresis on $12 \%$ to $20 \%$ polyacrylamide gel under denaturing conditions. Gel-purified oligos were eluted from the gel in water and desalted on NAP-10 columns.

\section{(c) Phosphorylation and ligation of oligodeoxynucle- otides}

Oligos used in the assembly of the synthetic $b F G F$ gene were phosphorylated as follows: $500 \mathrm{ng}$ of each purified oligo with the exception of numbers $1,8,9$, $14,15,22,23$, and 26 were incubated in $10 \mu$ of $70 \mathrm{mM}$ Tris $\cdot \mathrm{HCl}$, pH $7.6,10 \mathrm{mM} \mathrm{MgCl}_{2}, 5 \mathrm{mM}$ DTT, $10 \mu \mathrm{M}$ ATP, and $0.15 \mu \mathrm{M}\left[\gamma^{32}\right.$ P $]$ ATP (specific activity $6000 \mathrm{Ci} / \mathrm{mmol}$ ) containing 10 units of $\mathrm{T} 4$ polynucleotide kinase. After $1 \mathrm{~h}$ at $37^{\circ} \mathrm{C}$, the kinase was inactivated by heating to $95^{\circ} \mathrm{C}$ for $2 \mathrm{~min}$. After separating labeled DNA from unincorporated $\left[\gamma_{-}^{32} \mathrm{P}\right]$ ATP by chromatography through small columns of Bio-Gel-P2, the following subsets of oligos were mixed for ligation to the fragments A, B, $C$, and $C^{\prime}$, respectively: oligos Nos. 1-8, 9-14, 15-22, and 23-26. The indicated subsets were heated to $80^{\circ} \mathrm{C}$ for $10 \mathrm{~min}$ and then slowly cooled to $25^{\circ} \mathrm{C}$ over $1 \mathrm{~h}$ to allow the complementary strands to anneal.

Each solution was adjusted to $70 \mathrm{mM}$ Tris $\cdot \mathrm{HCl}$ pH 7.2, $100 \mathrm{mM} \mathrm{NaCl}, 10 \mathrm{mM} \mathrm{MgCl}_{2}, 1 \mathrm{mM}$ EDTA, and $5 \mathrm{mM}$ DTT. Then $0.5 \mathrm{mM}$ ATP T4 DNA ligase was added to 0.8 units per $10 \mu \mathrm{l}$ and the reaction mixture was incubated overnight at $16^{\circ} \mathrm{C}$. Fragments $\mathrm{A}, \mathrm{B}$, and $\mathrm{C}$ were purified in a $7 \mathrm{M}$ urea $12 \%$ polyacrylamide gel run in $90 \mathrm{mM}$ Tris, $90 \mathrm{mM}$ borate, and $2 \mathrm{mM}$ EDTA. The wet gel was autoradiographed overnight and the detected DNA fragments were electroeluted into dialysis bags. 
Each gel-purified fragment was incubated in $10 \mu \mathrm{l}$ of $50 \mathrm{mM}$ Tris $\cdot \mathrm{HCl}$, pH $7.6,10 \mathrm{mM} \mathrm{MgCl}_{2}, 5 \mathrm{mM}$ DTT, $0.1 \mathrm{mM}$ spermidine, $0.1 \mathrm{mM}$ EDTA, $0.125 \mathrm{mM}$ ATP, and 10 units of T4 polynucleotide kinase. After $1 \mathrm{~h}$ at $37^{\circ} \mathrm{C}$, the kinase was inactivated by heating to $95^{\circ} \mathrm{C}$ for $2 \mathrm{~min}$.

The cloning of the kinased fragments took place as follows: fragment A was ligated to $E c o \mathrm{RI}+$ Pst Idigested M13mp18; fragment $\mathrm{B}$ to $P s t \mathrm{I}+X b a \mathrm{I}-$ digested pGem 4, and fragment $C, C^{\prime}$ to $X b a \mathrm{I}+$ HindIII-digested M13mp18 using a 10:1 molar ratio of insert : vector. Each double-digested vector DNA was dephosphorylated prior to the insert ligation in $30 \mu \mathrm{l}$ of $50 \mathrm{mM}$ Tris $\cdot \mathrm{HCl}, \mathrm{pH} 9.5$, $50 \mathrm{mM}$ Tris $\cdot \mathrm{HCl}, \mathrm{pH} 9.5,50 \mathrm{mM} \mathrm{NaCl}, 0.5 \mathrm{mM}$ DTT, containing $1 \mu \mathrm{g}$ digested vector DNA and 1 unit of calf intestinal phosphatase. After incubation for $1 \mathrm{~h}$ at $50^{\circ} \mathrm{C}$, the enzyme was inactivated by adding $2 \mu \mathrm{l}$ of $0.5 \mathrm{mM}$ EDTA.

\section{(d) Plasmid construction and DNA cloning}

Standard procedures were used for plasmid purification (Birnboim and Doly, 1979), transformation (Mandel and Higa, 1970) and DNA sequencing (Sanger et al., 1977). Large plasmid fragments were separated by agarose gel electrophoresis followed by electroelution on DEAE-NA45 membranes.

\section{(e) Isolation of recombinant basic fibroblast growth factor}

\section{(1) Cell lysis}

$250 \mathrm{ml}$ of an appropriate culture was centrifuged for $15 \mathrm{~min}$ at $4000 \mathrm{rev} . / \mathrm{min}$. and $0^{\circ} \mathrm{C}$. The cell pellet was resuspended in $4 \mathrm{ml}$ buffer $\mathrm{L}(50 \mathrm{mM}$ Tris $\cdot \mathrm{HCl}$, pH 8.0, $10 \mathrm{mM}$ EDTA) containing $25 \%$ sucrose. After adding $6 \mathrm{mg}$ lysozyme in $1.2 \mathrm{ml}$ buffer $\mathrm{L}$ and $2.4 \mathrm{ml}$ of $0.25 \mathrm{M}$ EDTA, $0.25 \mathrm{M}$ Tris $\cdot \mathrm{HCl}, \mathrm{pH} 8.0$, the mixture was incubated for $1 \mathrm{~h}$ at $0^{\circ} \mathrm{C}$. Then $10 \mathrm{ml}$ of $2 \%$ Triton $\mathrm{X}-100$ in buffer $\mathrm{L}$ was added and, following sonication at $0^{\circ} \mathrm{C}$, soluble and insoluble material was separated by centrifugation for $17 \mathrm{~min}$ at $6000 \mathrm{rev} . / \mathrm{min}$. The pellet containing bFGF inclusion bodies was washed twice with $2 \%$ Triton $\mathrm{X}-100$ in buffer $\mathrm{L}$ and used for purification (see subsection 3, below).

\section{(2) Purification of soluble FGF}

The supernatant remaining after cell lysis (see subsection 1 , above) was applied to a CM Sephadex C- 50 column ( $10 \mathrm{ml}$ bed volume, diameter $4 \mathrm{~cm}$, flow rate $100 \mathrm{ml} / \mathrm{h}$, at room temperature), washed with $0.1 \mathrm{M} \mathrm{Na} \cdot$ phosphate, $\mathrm{pH} 6.5,0.15 \mathrm{M} \mathrm{NaCl}$, and eluted with $0.1 \mathrm{M} \mathrm{Na}$. phosphate, $\mathrm{pH} 6.5,0.6 \mathrm{M}$ $\mathrm{NaCl}$. The eluate was applied to heparin-Sepharose column ( $2 \mathrm{ml}$ bed volume, diameter $1 \mathrm{~cm}$, flow rate $50 \mathrm{ml} / \mathrm{h}$ ). The column was washed with $10 \mathrm{mM}$ Tris $\cdot \mathrm{HCl}, \mathrm{pH} 7.0,0.8 \mathrm{M} \mathrm{NaCl}$ and eluted with $10 \mathrm{mM}$ Tris $\cdot \mathrm{HCl}, \mathrm{pH} 7.0,2.0 \mathrm{M} \mathrm{NaCl}$. The eluate was dialysed against $50 \mathrm{mM}$ ammonium formate and lyophilized.

\section{(3) Preparation of bFGF from inclusion bodies}

The washed pellet obtained after cell lysis (see subsection 1 , above) was solubilized in $10 \mathrm{ml}$ buffer $\mathrm{L}$ containing $6 \mathrm{M}$ guanidinium $\cdot \mathrm{HCl}$ and $0.25 \mathrm{M}$ DTT and incubated for $2 \mathrm{~h}$ at $50^{\circ} \mathrm{C}$. Buffer $\mathrm{L}(30 \mathrm{ml})$ was then added slowly with vigorous stirring and simultaneous slow cooling to $30^{\circ} \mathrm{C}$. After dialyzing against $10 \mathrm{mM}$ Tris $\cdot \mathrm{HCl}, \mathrm{pH} 7.0,0.8 \mathrm{M} \mathrm{NaCl}$ and subsequent centrifugation, the supernatant was applied directly to a heparin-Sepharose column as described above.

\section{(f) Preparation of rabbit anti-bovine basic fibroblast growth factor}

A peptide corresponding to the 19 aa (FPPGHFKDPKRLYCKNGGF) near the $\mathrm{N}$ terminus of bovine bFGF (Esch et al., 1985) was synthesized by solid-phase methods using a Biosearch peptide synthesizer. The synthetic peptide was purified by reverse-phase HPLC and then coupled to BSA using 1-ethyl-3-(3-dimethylaminopropyl) carbodiimide (EDC; Shapira et al., 1984). Rabbits were immunized with $0.5 \mathrm{mg}$ of the BSApeptide conjugate emulsified with complete Freund's adjuvant. Three weeks later, a booster injection was given using $0.3 \mathrm{mg}$ of the conjugate emulsified in incomplete Freud's adjuvant. Sera were tested by Western blot analysis (see section $\mathbf{h}$, below) using bovine brain-derived bFGF. 


\section{(g) SDS-PAGE and silver staining}

Growth factor fractions from various purification steps were dialyzed against $50 \mathrm{mM}$ ammonium formate overnight, lyophilized, boiled in sample buffer, and analyzed on SDS-15\% PAGE (Laemmli, 1970). After electrophoresis the polypeptide bands were visualized by silver staining (Oakley et al., 1980).

\section{(h) Western-blot analysis}

For Western immunoblotting analysis, electrophoretically separated polypeptides were transferred onto nitrocellulose at $0.3 \mathrm{~mA} / \mathrm{cm}^{2}$ in $20 \mathrm{mM}$ Tris, pH 7.4, $150 \mathrm{mM}$ glycine, and $20 \%$ methanol overnight (Towbin et al., 1979). To block nonspecific binding, the nitrocellulose was incubated with PBS containing $3 \%$ BSA for $1 \mathrm{~h}$ at room temperature and washed twice with PBS containing $0.1 \%$ Tween-20.

The first antibody reaction was carried out by incubating the nitrocellulose with a 1000 -fold dilution of the rabbit anti-bovine bFGF antibody in PBS containing $0.1 \%$ Tween- 20 and $1 \%$ BSA for $2 \mathrm{~h}$ at room temperature followed by 3 washing steps with PBS containing $0.1 \%$ Tween-20. The nitrocellulose was then incubated with a 500 -fold dilution of the peroxidase-conjugated goat anti-rabbit IgG antibody for $1 \mathrm{~h}$ at room temperature followed by washing.

The immunoreaction was visualized using $0.5 \mathrm{mg} / \mathrm{ml}$ diaminobenzidine $\cdot \mathrm{HCl}$ in $50 \mathrm{mM}$ Tris $\cdot \mathrm{HCl}, \mathrm{pH} 7.6,100 \mathrm{mM} \mathrm{NaCl}, 0.4 \%$ nickel sulfate, and $0.01 \% \mathrm{H}_{2} \mathrm{O}_{2}$.

\section{(i) Proliferation assay}

Fractions were assayed for growth factor activity on BAE cells as described (Risau, 1986). Briefly, cells were resuspended in DMEM supplemented with $4 \%$ FCS, glutamine $(0.5 \mathrm{mg} / \mathrm{ml})$, and penicillin/streptomycin (100 units $/ \mathrm{ml})$, and plated (10000 cells $/ 0.5 \mathrm{ml}$ per well) on 24 -well plates. Unattached cells were removed one day later and $0.5 \mathrm{ml}$ of fresh supplemented DMEM containing growth-factor fractions was added. After three days of incubation, cells were detached from the plates using trypsin/EDTA solution and counted in a coulter counter.

\section{(j) In vivo assay}

Heparin-Sepharose-purified recombinant bFGF in Elvax polymers (Langer et al., 1986) was implanted into rabbit corneal pockets as described (Gimbrone et al., 1974; Risau, 1986).

\section{RESULTS AND DISCUSSION}

\section{(a) Construction of the bovine and human bFGF} gene

A synthetic gene encoding the 146 aa of bovine bFGF was designed on the basis of the known amino acid sequence (Esch et al., 1985). The selection of the precise nucleotide sequence for the gene was influenced by the following considerations: (1) The high frequency of a set of statistically 'preferred' codons among highly cxpressed $E$. coli genes; (2) the obvious convenience of introducing unique restriction endonuclease recognition sites into the sequence; and (3) the need to avoid the presence of excessively stable secondary structures in the encoded mRNA, especially in the early part of the cistron.

Twenty-two oligos ranging in size from 24 to $52 \mathrm{nt}$ were synthesized, purified, and assembled to form the synthetic bovine $b F G F$ gene (Fig. 1). To assemble the gene, subsets of oligos were ligated to generate the fragments $\mathrm{A}, \mathrm{B}$, and $\mathrm{C}$. These fragments were purified by PAGE under denaturing conditions, phosphorylated, and ligated to appropriately digested, dephosphorylated vectors. The resulting hybrid plasmids werc transferred into $E$. coli cells.

Clones containing the predicted DNA inserts as determined by double-digestion of the respective plasmid DNA were selected for the preparation of larger quantities of the $\mathrm{A}, \mathrm{B}$, and $\mathrm{C}$ fragments, which were subsequently isolated and annealed. The resulting synthetic gene was ligated to Eco RI + HindIIdigested pUC8 and used to transform $E$. coli HB10l. A clone containing the predicted nucleotide sequence, as determined by Sanger et al. (1977) sequencing, was designated pUC8ABC.

The synthetic gene encoding the 146 aa of the human bFGF was initially constructed by exchanging fragment $\mathrm{C}$ of $\mathrm{pUC} 8 \mathrm{ABC}$ for a further fragment 
$\mathrm{C}^{\prime}$ (Fig. 1) that was synthesized according to the published sequence of human $b F G F$ (Abraham et al., 1986). N-terminally extended forms of the gene were constructed by exchanging the first part of the synthetic sequence with appropriate oligo pairs.

\section{(b) Expression of basic fibroblast growth factor}

Plasmid pUC12, an M13mp7-derived system (Vieira and Messing, 1982), was doubly digested with SmaI + HindIII, dephosphorylated, and ligated Prominent polypeptides with apparent $M_{\mathrm{r}} \mathrm{s}$ of

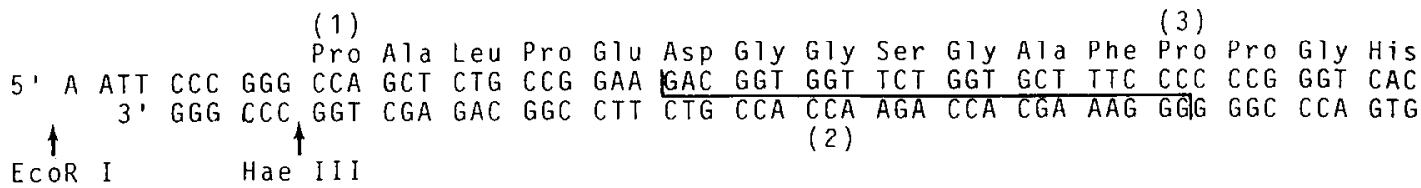

Phe Lys Asp Pro Lys Arg Leu Tyr Cys Lys Asn Gly Gly Phe Phe Leu Arg Ile His TTC AAA GAC CCG AAA CGUT CTG TAC TGC AAA AAC GGT GGT TTC TTC CTG CGT ATC CAC AAG TTT CTG GGC TTT GCA GAC ATG ACG TTT TTG CCA CCA AlAG AAG GAC GCA TAG GTG (4)

Pro Asp Gly Arg Val Asp Gly Val Arg Glu Lys Ser Asp Pro His lle Lys Leu Gln CCG GAC GGT CGT GTT GAC GGT GTT CGT GAA AAA TCC GAC CCG CAC ATC AAA CTC CAA GGC CTG CCA GCA CAA CTG CCA CAA GCA CTT TTT AGG CTG GGC GTG TAG TTT GAG GTT (6)

\section{(9)}

Leu Gln Ala Glu Giu Arg Gly Val Val Ser Ile Lys Gly Val Cys Ala Asn Arg Tyr CTG CAIG GTT GAA GAA CGT GGT GTT GTT TCL ATC AAA GGT GTT TGC GCT AAC CGT TAC. GIAC GTC CGA CTT CTT GCA CCA CAA CAA AGG GAG TTT CCA CAA ACG CGA TTG GCA ATG $\uparrow_{\text {pst I }}$ (10)

Leu Ala Met Lys Glu Asp Gly Arg Leu Leu Ala Ser Lys Cys Val Thr Asp Glu Cys CTG GCT ATG AAA GAA GAC GGT CGT CTG CTG GCT TCC AAA TGC GTT ACC GAC GAM TGC GAC CGA TAC TTT CTT CTG CCA GCA GAC GAC CGA AGG TTT ACG CAA TGG CTG CTT ACG (12)

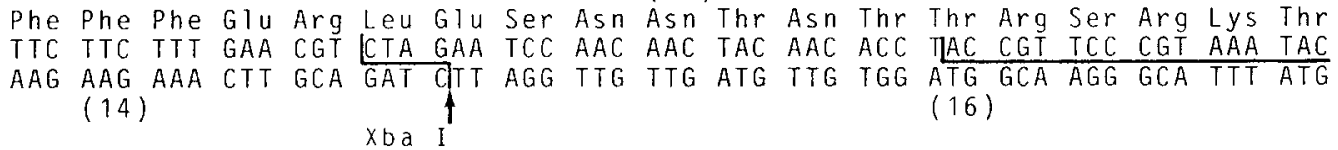
(14) $x \circ \mathrm{I}$ (16)

Ser Ser Trp Tyr Val Ala LCu Lys Arg Thr Gly Gln Tyr Lys Leu Gly Pro Lys Thr TCC TCC TGG TAC GTT GCT CTG AAA CGT ACC GGT LCAG TAC AAA CTG GGT CCG AAA ACC AGG AGG ACC ATG CAA CGA GAC TTT GCA TGG CCA GTC ATG TTT GAC CCA GGC TTT] TGG (18)

(21)

Giy Pro Gly Gin Lys Ala Ile Leu Phe Leu Pro Met Ser Ala Lys Ser * *

GGT CCG GGT CAG AAA IGCT ATC CTG TTC CTG CCG ATG TCC GCT AAA TCC TAA TA

CCA GGC CCA GTC TTT CGA TAG GAC AAG GAC GGC TAC AGG CGA TTT AGG ATT ATT CGA (20)

(22)

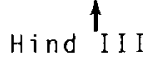

Fig. 1. Nucleotide sequence of the synthetic bovine $b F G F$ gene. Numbers in parentheses identify the 22 oligos used in the gene assembly. The lines denote the ends of the oligos and the respective overlapping regions between fragments. Unique restriction sites are marked by upward arrows. Asterisks represent stop codons. The human $b F G F$ nucleotide sequence was obtained by exchanging the underlined base pairs T/A of a Ser codon and C/G of a Pro codon into A/T and T/A, respectively, resulting in codons for Thr and Ser. 
with the HaeIII-HindIII fragment of pUC8ABC containing the synthetic bovine bFGF nucleotide sequence. The resulting recombinant plasmid LD $1 / 2$ encodes a 156-aa fusion protein consisting of the first 7 aa of $\beta$-galactosidase, 3 aa encoded by part of the multiple cloning site, and the 146 aa of bovine bFGF.

Computer analysis of the translational initiation region of the pUC12-bbFGF encoded mRNA predicted a highly stable ( $\Delta \mathrm{G}$ at $37^{\circ} \mathrm{C}=-14 \mathrm{kcal}$ ) hairpin loop structure immediately adjacent to the Shine-Dalgarno region (Fig. 2a). Such a structure would be expected to impinge on translational initiation (see, e.g., McCarthy and Bokelmann, 1988).

In the case of human bFGF a number of constructs differing in the nature of the $\mathrm{N}$-terminal part of the synthetic gene were subjected to analysis. Extra codons, corresponding to part or all of the $\mathrm{N}$-terminal extension to the 146-aa form of bFGF identified by nucleotide sequencing ( $\Lambda$ braham et al., 1986), were included in these constructs. One construct encoded the full 155 aa described by Abraham et al. (1986). The extra N-terminal sequence was borne on an NdeI-HindIII DNA fragment, whereby the codon usage was adjusted to prevent the formation of highly stable secondary structure within the translational initiation region formed upon insertion of this new synthetic gene into the expression vector pJLA503 (Fig. 2b). The 155-codon gene, containing the NdeI-HindIII fragment, was initially subcloned into pCB179 (Schneider and Beck, 1987). It was subsequently excised as an NdeI-SalI fragment and inserted into appropriately cleaved pJL $\Lambda 503$. The latter expression vector is one of a series of plasmids derived from $\mathrm{pJLf} 201$ bearing part of the $E$. coli atp $E$ TIR (McCarthy et al., 1986; Schauder et al., 1987). Transcription in these plasmids is initiated by the $\lambda$ bacteriophage major $p_{\mathrm{R}}$ and $p_{\mathrm{L}}$ promoters (in tandem) and is repressed by the product of the plasmid-borne $c$ Its 857 gene.

Correct recombinant products, bearing the fused bovine bFGF in pUC12 (LD1/2) and the unfused, fully extended human bFGF in pJLA503 (T36/9), were transferred into $E$. coli cells (strain $\mathrm{R} 1180: \mathrm{sc} 122$, lon $^{-}, h t p R^{-}$). Transcription of the human $b F G F$ gene was repressed by the $\lambda c$ Its875coded repressor when cultures of R1180-T36/9 were grown at $30^{\circ} \mathrm{C}$. A temperature shift from $30^{\circ} \mathrm{C}$ to $42^{\circ} \mathrm{C}$ allowed synthesis of large amounts of human bFGF via inactivation of the $\lambda$ cIts857-coded repressor (Fig. 3). Cultures of R1180[pJLA503] (vector minus DNA insert) grown at $30^{\circ} \mathrm{C}$ and $42^{\circ} \mathrm{C}$ served as controls. The bovine $\mathrm{bFGF}$ fusion protein encoded by LD1/2 was expressed constitutively in strain R1180.

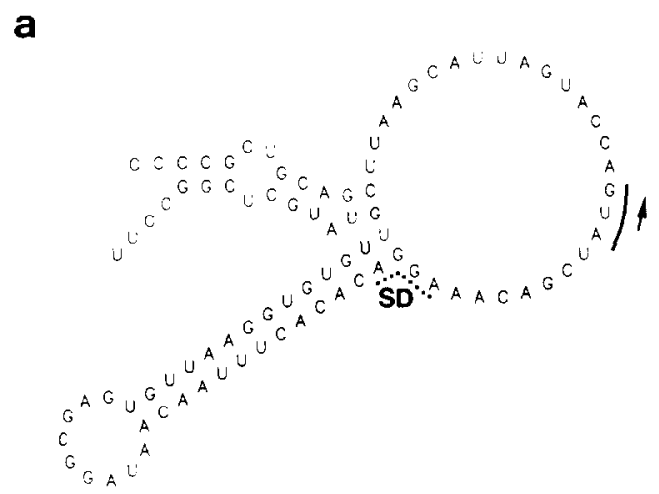

b

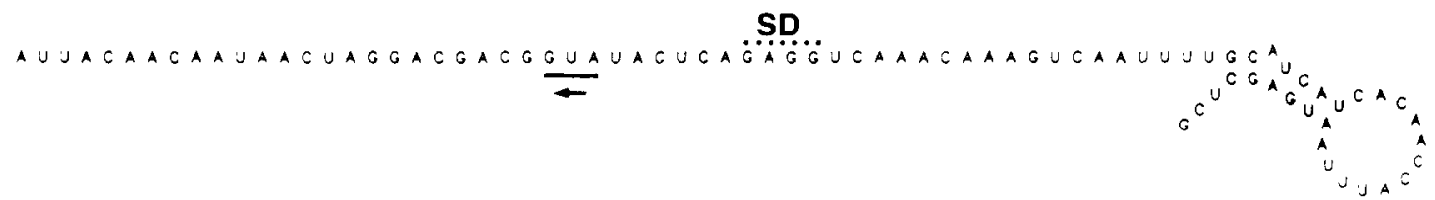

Fig. 2. Secondary structures predicted for the mRNA TIRs encoded by (a) pUC12-bbFGF and (b) pJLA503-hbFGF (Zuker and Stiegler, 1981). The predicted free energies of base pairing were $-14 \mathrm{kcal}$ (pUCI2bbFGF) and $+0.2 \mathrm{kcal}$ (pJLA503-hbFGF) for the regions shown. 


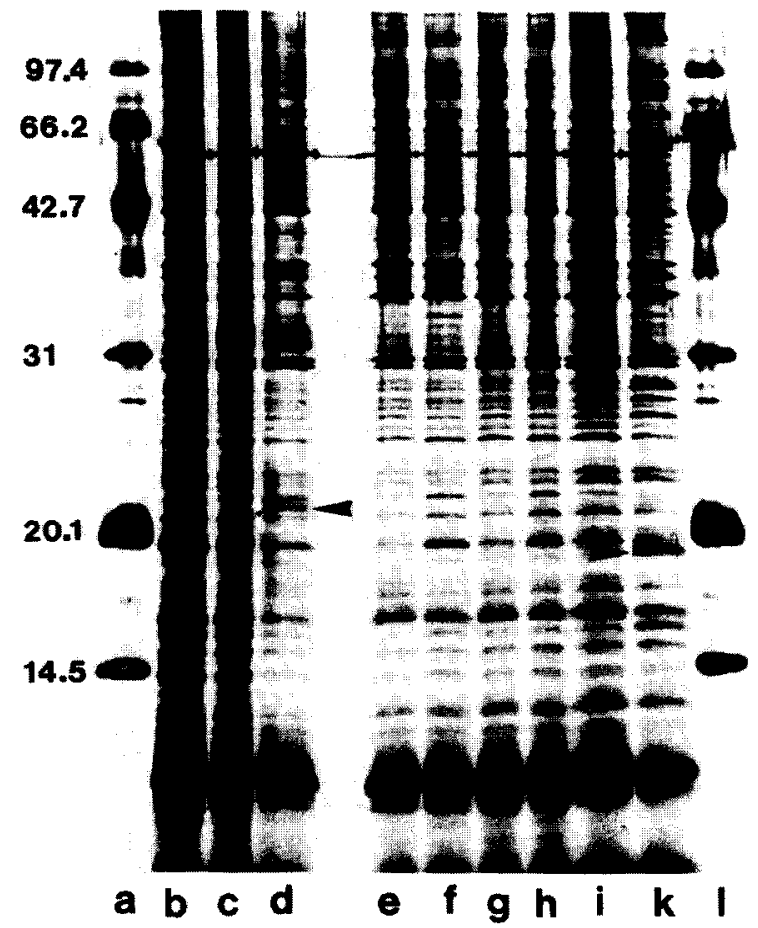

Fig. 3. SDS-15\% PAGE analysis of recombinant $b F G F$ expression. Cultures of pUC12 (vector only) and LD1/2 (vector + bFGF) were grown overnight at $37^{\circ} \mathrm{C}$ (final $A_{600 \mathrm{~nm}}=4$ ); cultures of pJLA503 (vector only) and T36/9 (vector $+b F G F$ ) $E$. coll $\mathrm{R} 1180$ were grown at $30^{\circ} \mathrm{C}(A 1)$, then induced for $3 \mathrm{~h}$ at $42^{\circ} \mathrm{C}(A 2)$. Each culture was then diluted to an $A$ of $0.5 ; 40 \mu 1$ along with $20 \mu \mathrm{l}$ of loading buffer were boiled for $10 \mathrm{~min}$. Of each sample solution $10 \mu \mathrm{l}$ were loaded onto the gel. Lanes: $\mathbf{a}$ and $\mathbf{I}$, molecular size protein standards (in $\mathrm{kDa}$, as indicated at the left); b, R 1180 cells, $37^{\circ} \mathrm{C}$; c, R1180[pUC12] DNA, $37^{\circ} \mathrm{C}$; d, R1180[pUC12-bbFGF], $37^{\circ} \mathrm{C}$; e, R 1180 cells, $30^{\circ} \mathrm{C}$; f, R 1180 cells, $42^{\circ} \mathrm{C}$; g, R1180[pJLA503] DNA, $30^{\circ} \mathrm{C}$; h, R1180[pJLA503], $42^{\circ} \mathrm{C}$; i, R1180[pJLA503-hbFGF], $30^{\circ} \mathrm{C} ; \mathbf{k}, \mathrm{R} 1180-$ [pJLA503-hbFGF], $42^{\circ} \mathrm{C}$. The arrows indicate the protein encuded by $\mu$ UC12bbFGF (lane d) and by pJLA503-hbFGF (lane k), respectively.

$18 \mathrm{kDa}$ and $20.5 \mathrm{kDa}$ were present in extracts of induced $E$. coli cultures of R1180[T36/9] and R1180[LD1/2], respectively. These proteins were absent in extracts from control cultures.

Recombinant growth factors were purified from $E$. coli cells using a procedure established for the purification of bFGF from bovine brain (Lobb et al., 1986; Risau et al., 1988). Cells were lysed by a combination of Triton X-100 and mild lysozyme treatment. Following sonication the extracts were clarified by centrifugation.

The supernatant was applied to a CM-Sephadex C-50 cation exchange column. The column was washed and growth factor activity eluted using $0.6 \mathrm{M}$ $\mathrm{NaCl}$. Heparin-Sepharose affinity chromatography was used as the second step in purification. Almost all of the extraneous protein present in the Sephadex eluate was separated from growth factor activity in this sccond step. The FGF activity itself could be eluted using $2 \mathrm{M} \mathrm{NaCl}$. Sephadex and subsequent heparin-Sepharose-purified growth factor fractions were analyzed by the SDS-PAGE, followed by silver staining or immunoblotting using polyclonal antibodies prepared against a bFGF peptide. Cells transformed by LD $1 / 2$ plasmid encoding the bovine $\mathrm{bFGF} / \beta$-galactosidase fusion protein synthesized a protein of $20.5 \mathrm{kDa}$ (Fig. $4 \mathrm{a}$ ), which is the expected size calculated from the encoded mRNA.

Recombinant human $\mathrm{bFGF}$ encoded by the plasmid T36/9 should have an $M_{\mathrm{r}}$ of 18000 and a protein of approximately this size could be observed after induction (Fig. 4b). Natural bovine brain bFGF served as a control (Fig. 4a). An immunoreactive peptide of lower $M_{\mathrm{r}}$, probably a product of proteolytic degradation, was also detected using the antibody. Recombinant bovine bFGF fusion protein appeared as a doublet (Fig. 4a), a phenomenon that has also been described for the brain-derived bovine bFGF (Lobb et al., 1986).

FGF was also present in cytoplasmic inclusion bodies, as is often observed with other recombinant proteins expressed at a high level in E. coli (Kleid et al., 1981; Simons et al., 1984; Schoner et al., 1985). Proteins in such inclusion bodies are generally soluble only under denaturing conditions. Thus, the pellet fraction obtained after centrifugation of lysed cells was solubilized in a large volume of guanidinium $\cdot \mathrm{HCl}$ together with $0.2 \mathrm{M}$ DTT to cleave possible intermolecular disulfide bonds. For renaturation the treated pellet fraction was carefully diluted and dialysed to prevent aggregation of bFGF. The cleared dialysate was directly applied to a heparin-Sepharose affinity column as described above.

(c) Biological activities of bovine and human recombinant fibroblast growth factor

The purified growth factors were analyzed for mitogenic activity on BAE cells. In this assay, the maximal stimulation observed with brain-derived bovine was similar to that with recombinant human 
A

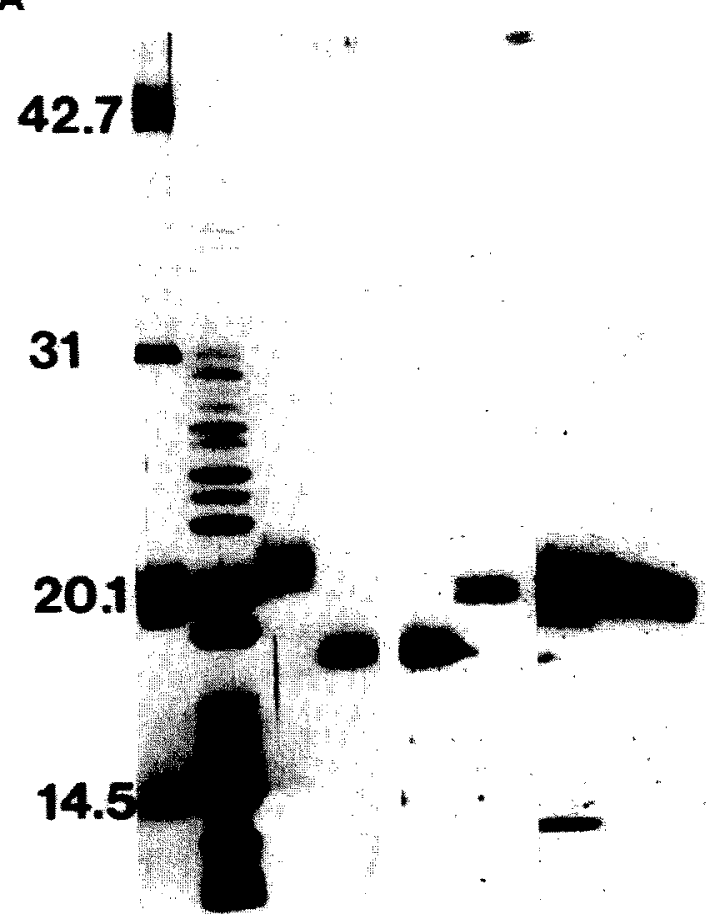

a b c d e f $\mathrm{g}$
B

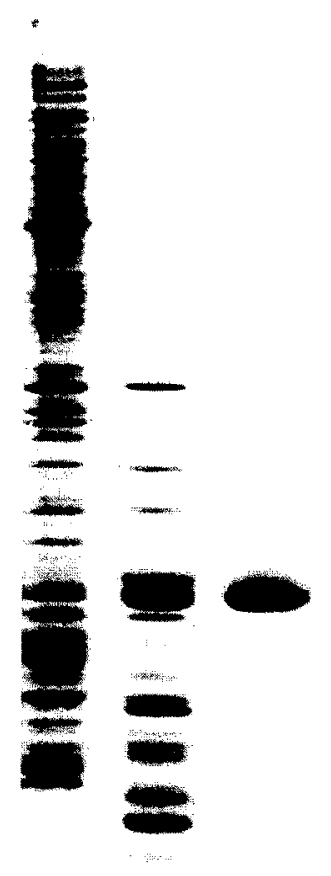

31

20.1

97.4

68.2

42.7

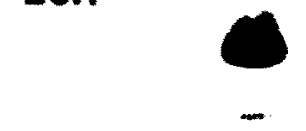

14.5

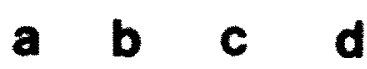

e

Fig. 4. SDS-PAGE and Western blot analysis of different FGF purification steps. Samples containing about $1 \mu \mathrm{g}$ protein were separated by SDS-15\% PAGE, transferred onto nitrocellulose, incubated with anti-bFGF antibodies, and then reacted with a peroxidaseconjugated goat anti-rabbit IgG antibody. (Panel A) Bovine bFGF: lanes a-d, silver stained peptides; e-h, immunoblot; a, molecular size protein standards (kDa as indicated at the left); b,f, CM Sephadex C50 eluate; $\mathbf{c , g , h}$, heparin-Sepharose eluate; d,e, brain-derived bovine bFGF. (Panel B) Human bFGF: lanes: a-d, silver stained peptides; a, cell lysate (RI180[pJLA503-hbFGF], 42 ${ }^{\circ} \mathrm{C}$ ); b, CM Sephadex C50 eluate; c, heparin-Sepharose eluate; $\mathbf{d}$, molecular size protein standards ( $\mathrm{KDa}$ as indicated between lanes $\mathbf{d}$ and $\mathbf{e}$ ); $\mathbf{e}$, immunoblot, heparin-Sepharose eluate.

$\mathrm{bFGF}$, as were the concentrations giving halfmaximal stimulation $\left[\mathrm{ED}_{\mathrm{so}}\right.$ brain-derived bovine bFGF $0.2 \mathrm{ng} / \mathrm{ml}, \mathrm{ED}_{\mathrm{so}}$ recombinant human $\mathrm{bFGF}$ (isolated from the supernatant) $0.14 \mathrm{ng} / \mathrm{ml}$ ] (Fig. 5). The recombinant human $\mathrm{bFGF}$ isolated from the pellet fraction showed a somewhat lower $\mathrm{ED}_{50}$ of $0.5 \mathrm{ng} / \mathrm{ml}$. The lower specific activity of the human bFGF pellet preparation might be due to the incomplete formation of disulfide bonds that may be important to the correct conformation of bFGF (cf., e.g., aFGF; Thomas et al., 1988). The recombinant bovine bFGF fusion protein showed an $\mathrm{ED}_{50}$ of $0.95 \mathrm{ng} / \mathrm{ml}$, probably owing to the presence of additional $\beta$-galactosidase amino acids at the $\mathrm{N}$ terminus of the molecule.
We also examined the in vivo activity of recombinant bovine bFGF fusion protein and the human bFGF. In rabbit corneas, new sprouts originating from the limbal vascular system penctrated the avascular cornea two days after implantation of Elvax polymers containing $500 \mathrm{ng}$ of recombinant human $b F G F$ and reached the polymer ten days later (Fig. 6). Similarly, recombinant bovine bFGF fusion protein stimulated angiogenesis in the rabbit cornea (not shown). No neovascularization was seen in corneas in which control polymers had been implanted. No inflammation was observed, except for an initial slight cloudiness of some corneas, which disappeared about four days after implantation. 


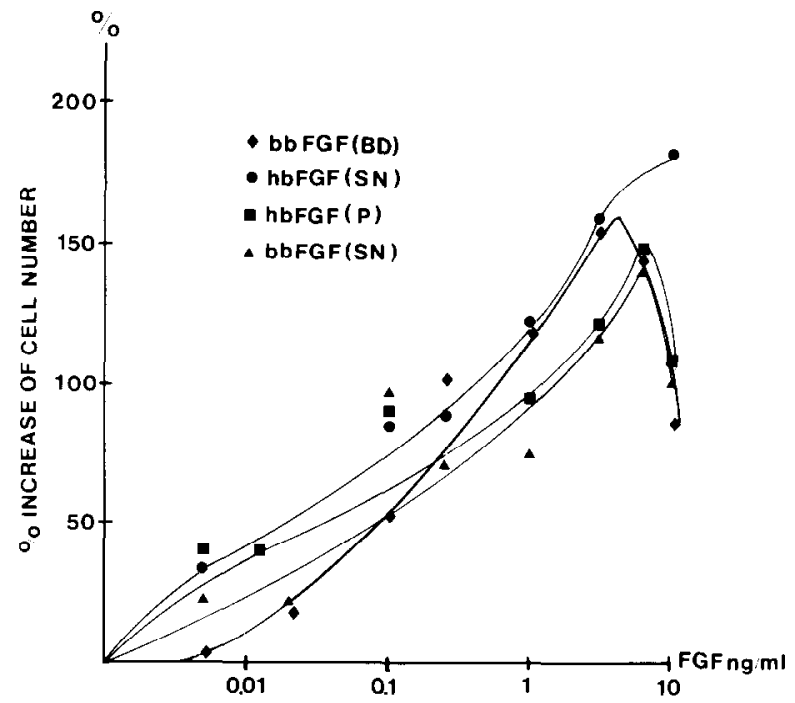

Fig. 5. Proliferation of BAE cells as a function of medium supplement (DMEM supplemented with calf serum and different bFGF preparations). $10^{4}$ cells $/ 20 \mathrm{~mm}$ well were seeded in Costar plates as described in MATERIALS AND METHODS, section i. Cells were exposed to medium containing $4 \%$ FCS and increasing amounts of growth-factor fractions. $\rightarrow$, Brain-derived (BD) bovine bFGF, $\mathrm{ED}_{50}, 0.2 \mathrm{ng} / \mathrm{ml} ; \boldsymbol{\Delta}$, recombinant bovine bFGF fusion protein, supernatant ( $\mathrm{SN}$ ) $\mathrm{ED}_{50}, 0.95 \mathrm{ng} / \mathrm{ml} ; \boldsymbol{\bullet}$, recombinant human bFGF, supernatant $\mathrm{ED}_{50}, 0.14 \mathrm{ng} / \mathrm{ml} ; \mathbf{\square}$, recombinant human $\mathrm{bFGF}$, pellet $(\mathrm{P}) \mathrm{ED}_{50}, 0.5 \mathrm{ng} / \mathrm{ml}$.

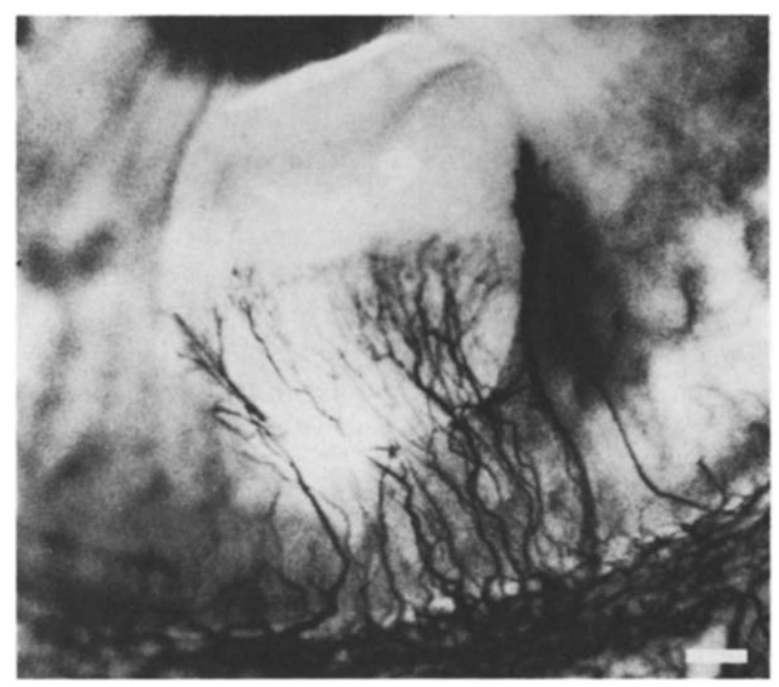

Fig. 6. Angiogenic activity of recombinant human bFGF. Elvax pellets containing $500 \mathrm{ng}$ protein of the heparin-Sepharose purified recombinant bFGF along with rabbit serum albumin to achieve $20 \%$ loading of the polymer were implanted into rabbit corneal pockets (four corneas). Capillaries were seen invading the cornea after two days and reached the polymers approx. ten days later. The photograph was taken 18 days after implantation. Bar, $1 \mathrm{~mm}$.

\section{(d) Conclusions}

Biologically active recombinant bovine bFGF fusion protein and human bFGF encoded by chemically synthesized genes were isolated in high yield and high purity. They were obtained as a single band on SDS-PAGE (Fig. 4a,b). Quantitation of the expressed growth factors was carried out using the Biorad protein assay.

The described plasmid constructions in the selected E. coli strains directed the synthesis of $0.5 \mathrm{mg}$ bovine bFGF protein and $5 \mathrm{mg}$ human bFGF protein per liter culture medium per $1 A_{600 \mathrm{~nm}}$ isolated from the soluble fraction of the cell extracts.

Three to four times the quantity of biologically active growth factor protein could certainly be obtained from the insoluble material that is also present in the induced cells. This would necessitate the successful renaturation of solubilized inclusion bodies. Large quantities of recombinant bFGF should help us to elucidate the biological function of bFGF in vivo as well as to investigate its potential application under pathological conditions such as wound healing (Sprugel et al., 1988), nerve regeneration (Baird et al., 1988), and cardiac infarction.

\section{ACKNOWLEDGEMENTS}

We are grateful to Drs. H.-R. Rackwitz and M. Schnölzer-Rackwitz for synthesizing the oligodeoxynucleotides and subcloning fragments $\mathrm{A}$ and $\mathrm{C}$. We thank I. Helmreich and U. Fasching for expert technical assistance, A. Friedlein for synthesizing the peptide, B. Rak for the generous gift of E. coli strain R1180, M. Schorpp for excellent animal care, and $P$. Bock for typing the manuscript.

\section{REFERENCES}

Abraham, J.A., Mergia, A., Whang, J.L., Tumolo, A., Friedman, J., Hjerrild, K.A., Gospodarowicz, D. and Fiddes, J.C.: Nucleotide sequence of a bovine clone encoding the angiogenic protein basic fibroblast growth factor. Science 233 (1986a) 545-458.

Abraham, J.A., Whang, J.L., Tumolo, A., Mergia, A., Friedman, J., Gospodarowicz, D. and Fiddes, J.C.: Human basic fibro- 
blast growth factor: nucleotide sequence and genomic organization. EMBO J. 5 (1986b) 2523-2528.

Baird, A., Cuevas, P., Gonzalez, A., Emoto, N., Feige, J.-J. and Walicke, P.: Fibroblast growth factors, the extracellular matrix and the regulation of the neovascular response. Cell. Biochem. Suppl. 12 A (1988) 73.

Birnboim, H.C. and Doly, J.: A rapid alkaline procedure for screening recombinant plasmid DNA. Nucleic Acids Res. 7 (1979) 1513-1523.

Esch, F., Baird, A., Ling, N., Ueno, N., Hill, F., Denoroy, L., Klepper, R., Gospodarowicz, D., Böhlen, P. and Guillemin, R.: Primary structure of bovine pituitary basic fibroblast growth factor (FGF) and comparison with the aminoterminal sequence of bovine brain acidic FGF. Proc. Natl. Acad. Sci. USA 82 (1985) 6507-6511.

Folkman, J.: Tumor angiogenesis. Adv. Cancer Res. 43 (1985) $175-203$.

Folkman, J. and Klagsbrun, M.: Angiogenic factors. Science 235 (1987) 442-447.

Gimbrone, M., Cotran, R.S., Leapman, S.B. and Folkman, J.: Tumor growth and neovascularization: an experimental model using the rabbit cornea. J. Natl. Cancer Inst. 52 (1974) 413-427.

Gospodarowicz, D., Neufeld, G. and Schweigerer, L.: Molecular and biological characterization of fibroblast growth factor, an angiogenic factor which also controls the proliferation and differentiation of mesoderm and neuroectoderm derived cells. Cell Diff. 19 (1986) 1-17.

Grantham, R., Gantier, C. and Gony, M.: Codon frequencies in 119 individual genes confirm consistent choices of degenerate bases according to genome type. Nucleic Acids Res. (1980) 1893-1912.

Grundström, T., von Gabain, A., Nilsson, G., Andersson, M., Lundström, M., Lund, B. and Lundgren, E.: Expression of an interfcron- $\alpha$ gene variant in $E$. coli using tandemly repeated synthetic ribosomal binding sites. DNA 6 (1987) 41-46.

Iwane, M., Kurokawa, T., Sasada, R., Seno, M., Nakagawa, S. and Igarashi, $\mathbf{K}$. : Expression of $\mathrm{cDNA}$ encoding human basic fibroblast growth factor in E. coli. Biochem. Biophys. Res. Commun. 146 (1987) 470-477.

Klagsbrun, M. and Shing, Y.: Heparin affinity of anionic and cationic capillary endothelial cell growth factor: analysis of hypothalamus-derived growth factors and fibroblast growth factors. Proc. Natl. Acad. Sci. USA 82 (1985) 805-809.

Klagsbrun, M., Smith, S., Sullivan, R., Shing, Y., Davidson, S., Smith, J.A. and Sasse, J.: Multiple forms of basic fibroblast growth factor: amino terminal cleavages by tumor cell- and brain cell-derived acid proteinases. Proc. Natl Acad. Sci. USA 84 (1987) 1839-1843.

Laemmli, U.K.: Cleavage of structural proteins during the assembly of the head of bacteriophage T4. Nature 227 (1970) 680-685.

Langer, R. and Folkman, J.: Polymers for the sustained release of proteins and other macromolecules. Nature 263 (1976) $797-800$.

Linemeyer, D.L., Kelly, L.J., Menke, J.G., Gimenez-Gallego, G., DiSalvo, J. and Thomas, K.A.: Expression in Escherichia coli of a chemically synthesized gene for biologically active bovine acidic fibroblast growth factor. Biotechnology 5 (1987) 960-964.

Lobb, R., Sasse, J., Sullivan, R., Shing, Y., D'Amore, P., Jacobs, J. and Klagsbrun, M.: Purification and characterization of heparin-binding endothelial cell growth factors. J. Biol. Chem. 261 (1986) 1924-1928.

Mandel, M. and Higa, A.: Calcium-dependent bacteriophage DNA infection. J. Mol. Biol. 53 (1970) 159-162.

McCarthy, J.E.G., Sebald, W., Gross, G. and Lammers, R.: Enhancement of translational efficiency by the Escherichia coli atpE translational initiation region: its fusion with two human genes. Gene 41 (1986) 201-206.

McCarthy, J.E.G. and Bokelmann, C.: Determinants of translational initiation efficiency in the atp operon of $E$. coli. Mol. Microbiol. (1988) in press.

Oakley, B.R., Kirsch, D.R. and Morris, N.R.: A simplified ultrasensitive silver stain for detecting proteins in polyacrylamide gels. Anal. Biochem. 105 (1980) 361-363.

Risau, W.: Developing brain produces an angiogenesis factor. Proc. Natl. Acad. Sci. USA 83 (1986) 3855-3859.

Risau, W., Gautschi-Sova, P. and Böhlen, P.: Endothelial cell growth factors in embryonic and adult chick brain are related to human acidic fibroblast growth factor. EMBO J. (1988) 959-962.

Sanger, F., Nicklen, S. and Coulson, A.R.: DNA sequencing with chain-terminating inhibitors. Proc. Natl. Acad. Sci. USA 74 (1977) 5463-5467.

Schauder, B., Blöcker, H., Frank, R. and McCarthy, J.: Inducible exprcssion vectors incorporating the Escherichia coli atpE translational initiation region. Gene 52 (1987) 279-283.

Schneider, K. and Beck, C.F.: Promoter-probe vectors for the analysis of divergently arranged promoters. Gene 42 (1986) $37-48$.

Shapira, H., Jibson, M., Müller, G. and Arnon, R.: Immunity and protection against influenza virus by synthetic peptide corresponding to antigenic sites of hemagglutinin. Proc. Natl. Acad. Sci. USA 81 (1984) 2461-2465.

Sprugel, K.H., Greenhalgh, D.G. and Ross, R.: Growth factors and wound repair. J. Biol. Chem. Suppl. 12A (1988) 74

Thomas, K., Gimenez-Gallego, G., Ortega, S., Disalvo, J., Soderman, D., Linemeyer, D., Kelly, L. and Menke, J.: Structure and function of acidic fibroblast growth factor. J. Biol. Chem. Suppl. 12A (1988) 66.

Towbin, H., Staehelin, T. and Gordon, J.: Electrophoretic transfer of proteins from polyacrylamide gels to nitrocellulose sheets: procedure and some applications. Proc. Natl. Acad. Sci. USA 76 (1979) $4350-4354$.

Vieira, $J$. and Messing, $J$.: The pUC plasmids, an M13mp7derived system for insertion mutagenesis and sequencing with synthetic universal primers. Gene 19 (1982) 259-268.

Zuker, M. and Stiegler, P.: Optimal computer folding of large RNA sequences using thermodynamics and auxiliary information. Nucleic Acid Res. 9 (1981) 133-148. 